\title{
Life Is Priceless: Mayan Q'eqchi' Voices on the Guatemalan National Reparations Program
}

\author{
Lieselotte Viaene*
}

\begin{abstract}
$^{1}$
Little in-depth research has been conducted on or attention paid to the experience and opinions of survivors regarding issues such as reparation, justice, reconciliation and truth in dealing with the aftermath of atrocities. Less still has been said of the way in which victims' identities impact on these views or are considered in the design of programs aimed at redress for past violations. This article focuses on Guatemala's National Reparations Program (PNR) as critically viewed by Mayan Q'eqchi' victims. The Q'eqchi' are the secondlargest Mayan group in the country and among the most severely affected by the internal armed conflict of 1960 to 1996. In Guatemala, the dominant culture is nonindigenous, although the majority of the population is indigenous Maya. This raises the complex issue of the actual and potential role of cultural context in dealing with grave human rights violations. In this regard, it is pertinent to establish how reparation is understood in different cultural contexts and to question how governmental reparations programs take these contexts into account. The results of extensive ethnographic field research conducted between 2006 and 2009 reveal the need for a locally rooted and culturally sensitive PNR.
\end{abstract}

\section{Introduction}

We want the president to listen to us, that our words may reach him, that he may know what happened. That he should pay attention to our words and believe that this truly happened. It is not a lie; we would never lie about what happened to us. If it had not happened, we would not have been able to come up with such a lie. Truly, that is what I want, for him to respond.

—Q'eqchi' widow, focus group discussion, 28 August 2007

* PhD researcher, Human Rights Centre, Ghent University, Belgium. Email: lieselotteviaene@ yahoo.com

1 An earlier version of this article was published as a chapter in the first report on the Guatemalan National Reparations Program. Lieselotte Viaene, 'La justicia transicional y contexto cultral en Guatemala: Voces Q'eqchi'es sobre el Programa Nacional de Resarcimiento,' in Primer informe temático 2006-2007 del Programa Nacional de Resarcimiento: La vida no tiene precio: Acciones y omisiones de resarcimiento de Guatemala (Guatemala City: Magna Terra, 2007). The author wishes to thank Eva Brems, Bernard Dumoulin, Alfonso Huet, Carlos Fredy Ochoa, Alfredo Chub, Nadine Janssens and Manuel Paau for their warmth during the field research and for their constructive comments on this article. Funding for this research was provided by the Research Foundation Flanders. Thanks is also due to Manuel Paau and all of the other Q'eqchi' for their participation in the research. Without their support, it would not have been possible. 
The challenge of redress for gross human rights violations invariably arises in postconflict societies that are in transition. One of the initiatives that a government is obligated to consider in response to survivor demands is a reparations program. Nonetheless, empirical studies that evaluate transitional justice efforts such as reparations programs from the perspective of the needs and preferences of survivors are rare. ${ }^{2}$ This article attempts to fill this gap by analyzing the Guatemalan National Reparations Program (Programa Nacional de Resarcimiento, or PNR) through the eyes of Mayan Q'eqchi' victims, a group heavily affected by Guatemala's internal conflict. ${ }^{3}$ In addition, it seeks to shed light on the role of cultural context in transitional justice programming, as well as to contribute to an emerging academic debate on the potential role of 'traditional justice' and broader cultural contexts in the politics of peace and reconciliation. ${ }^{4}$

Guatemala suffered the bloodiest armed conflict on the Latin American continent from 1960 until the peace agreements of 1996. State repression reached its peak between 1979 and 1983, when the government employed counterinsurgency tactics such as scorched earth campaigns and an imposed village patrol system known as the Civil Defense Patrols (Patrullas de Autodefensa Civil, or PACs). This resulted in the militarization of social life in rural indigenous areas. ${ }^{5}$ The conflict led to the death or disappearance of an estimated 200,000 people. It included 600 massacres, the destruction of over 400 villages, the internal displacement of one million people and a refugee stream of 150,000 to Mexico. ${ }^{6}$

According to the final report of the Commission for Historical Clarification (Comisión para el Esclarecimiento Histórico, or CEH), released in 1999, the

2 Sarah Cullinan, Torture Survivors' Perceptions of Reparation: Preliminary Survey (London: REDRESS, 2001); Due Process of Law Foundation, Después de procesos de justicia transicional: ¿Cuál es la situación de las víctimas?: Los casos de Chile y Guatemala (2007).

3 In light of my work, I prefer to use the term 'survivor,' which includes victims, returnees and internally displaced persons, as well as former PAC members. First, I agree with Mahmood Mamdani, who asserts that people should move beyond the dichotomy of victim-perpetrator as a way of searching for new forms of justice and coexistence. See, Mahmood Mamdani, When Victims Become Killers: Colonialism, Nativism, and the Genocide in Rwanda (Princeton, NJ: Princeton University Press, 2001). Second, the label 'victim' carries with it the connotation of a harmed person who is passive and even helpless, whereas 'survivor' implies an active party. In fact, in Guatemala in particular, the international community and national organizations have stimulated a victimized vision by emphasizing the suffering of the victims and ignoring their capacity to make choices, to resist and even to participate politically. See, for example, Matilde González, Se cambió el tiempo: Conflicto y poder en territorio K'iche' (Guatemala City: AVANCSO, 2002). When referring to the beneficiaries of the PNR, however, I use 'victim' because this is the term used in Guatemalan governmental and human rights discourses on reparation.

4 Luc Huyse and Mark Salter, eds., Traditional Justice and Reconciliation after Violent Conflict: Learning from African Experiences (Stockholm: International Institute for Democracy and Electoral Assistance, 2008); Lars Waldorf, 'Mass Justice for Mass Atrocity: Rethinking Local Justice as Transitional Justice,' Temple Law Review 79(1) (2006): 1-87.

5 See, Angela Delli Sante, Nightmare or Reality: Guatemala in the 1980s (Amsterdam: Thela Publishers, 1996); Jennifer G. Schirmer, The Guatemalan Military Project: A Violence Called Democracy (Philadelphia, PA: University of Pennsylvania Press, 1998).

6 Robert Carmark, ed., Harvest of Violence: The Maya Indians and the Guatemalan Crisis (Norman, OK: University of Oklahoma Press, 1992); Nunca Más: Informe del Proyecto Interdiocesano de Recuperación de la Memoria Histórica (Guatemala: Oficina de Derechos Humanos del Arzobispado de Guatemala, 1998) [hereinafter 'REMHI']; Comisión para el Esclarecimiento Histórico (CEH), Guatemala: Memoria del silencio (Tz'inil Na'Tab'Al) (Guatemala: CEH, 1999). 
Guatemalan state was responsible for 93 percent of the conflict's human rights violations, while the guerrillas were responsible for just 3 percent. Furthermore, the Commission located the root causes of the conflict in historical structural injustice toward and economic exclusion of the indigenous population. This was evidenced by the concentration of productive wealth in the hands of a privileged, nonindigenous minority, a history of racism and discrimination and increasingly exclusionary and antidemocratic state institutions. A further significant finding was that the majority of victims $(83.3 \%)$ were of indigenous Mayan origin. ${ }^{7}$

The broader research question underlying this article is how specific particularities of the Mayan Q'eqchi' culture could play a role, or are already playing a role today, in postconflict processes at the local level. In Guatemala, the indigenous Mayan population, most of which is almost entirely monolingual, constitutes the majority of the population. ${ }^{8}$ The Q'eqchi', the second-largest Mayan group in the country, were among the most severely affected by the conflict.

To address this question, extensive ethnographic field research was conducted in the Cobán municipality in the Alta Verapaz department, ${ }^{9}$ specifically the regions of Nimlasachal, Nimlaha'kok and Salacuim. Research took place over 20 months between July 2006 and May 2009. Methodological triangulation, or multiple data collection techniques, was used to reinforce an in-depth understanding of the research question. Over 25 semistructured focus group discussions with survivors, witnesses and former PAC members were organized in different communities. ${ }^{10}$ Opinions were canvassed regarding issues of violence, justice, reconciliation, coexistence, reparation and truth recovery. For the majority of the participants, this was the first opportunity to express their opinions regarding these issues. A few had testified to the CEH or the Recovery of Historical Memory (REMHI) project, headed by the Guatemalan archbishop's Human Rights Office, in the late 1990s.

To determine proper Q'eqchi' terms and concepts, a preliminary consultation was conducted with two linguists, as well as widows, elders, spiritual guides and two foreign aid workers who between them had more than 30 years of experience working with the Q'eqchi' people, in particular on projects of community reintegration. Furthermore, numerous formal and informal individual interviews were conducted with community leaders, spiritual guides and local and foreign

7 CEH, supra n 6 at vol. 2.

8 Rachel Sieder and Jessica Witchell, 'Advancing Indigenous Claims through the Law: Reflections on the Guatemala Peace Process,' in Culture and Rights: Anthropological Perspectives, ed. Jane K. Cowan, Marie-Bénédicte Dembour and Richard A. Wilson (Cambridge: Cambridge University Press, 2001). Guatemala has 22 Mayan ethnic groups, of which the Quiche, the Q'eqchi', the Kaqchikel and the Mam are the largest. According to a 2002 national census, the Mayan population represents just $43.6 \%$ of the entire population. It is acknowledged, however, that the statistics measuring the ethnic and cultural diversity in the country have severe limitations. See, UN Development Programme (UNDP), Diversidad étnico-cultural: La ciudadanía en un estado plural (2005).

9 According to the Municipal Planning Office in 2008, Cobán had the third-highest rural population density, with 414 villages.

10 A total of 173 people participated in the focus groups. All interviews were in Q'eqchi', with an interpreter, and were recorded. 
individuals with experience of the conflict and the social reconstruction process. Participant observation took place during community meetings, ceremonies and commemorative activities. The linguistic analysis in the third and fourth sections of the article are based on the results of three linguistic workshops conducted with legal translators, linguists and elders; on additional focus groups with elderly men and women; and on interviews with Q'eqchi' linguists and other Q'eqchi' individuals who have experience with Q'eqchi' internally displaced persons.

The first section of this article briefly explains the difficult road to reparation in Guatemala. In the sections that follow, the point of view of affected Mayan Q'eqchi' is explored. To frame this, a short background summary of the impact of the conflict in Alta Verapaz is provided. Next, the logical relations and semantic fields hidden in Q'eqchi' words that refer to the conflict are analyzed. The linguistic tangles between the Q'eqchi' and Spanish languages regarding redress, reparation and compensation are unraveled. An analysis is then provided of the PNR based on what emerged from the focus groups and research. This analysis yields concrete suggestions regarding the real preferences of the program's beneficiaries, including the necessity that the PNR be more locally and culturally sensitive.

\section{The Complicated Road to Reparations in Guatemala}

Peace negotiations in Guatemala spanned a total of 11 years and consisted of numerous agreements, with the 12th and final peace agreement being signed in December 1996. During the negotiations, the country was confronted with civil society demands to address the conflict's gross human rights violations. Reparation became a state commitment with the signing of the Comprehensive Agreement on Human Rights in 1994, which confirmed that assistance to victims of human rights violations is a humanitarian obligation. ${ }^{11}$ The $\mathrm{CEH}$ recommended the rollout, over 10 years, of an ambitious reparations program that would include restoration of material possessions, compensation, psychosocial reparation and rehabilitation, as well as restoration of individual dignity. ${ }^{12}$ A reconstruction of the creation of the PNR is beyond the scope of this article. Suffice to say it was a complex process that faced numerous obstacles and was defined by political struggle. ${ }^{13}$

Before looking at the PNR, it is necessary to shed light on some semantic issues regarding reparation in the Guatemalan context. Resarcimiento and reparación are the two Spanish terms commonly used in the debate on reparations. The term resarcir appeared for the first time in the Agreement on Human Rights. Since then, resarcimiento has been the term used by the Guatemalan state and civil society when

11 Comprehensive Agreement on Human Rights, Mexico City, Mexico (29 March 1994).

$12 \mathrm{CEH}$, supra n 6 at vol. 5.

13 See, UN Mission in Guatemala (MINUGUA), Informe de verificación: El estado de cumplimiento de las recomendaciones de la Comisión para el Esclarecimiento Histórico (2004); Gustavo Porras Castejón, 'El Programa Nacional de Resarcimiento: Cómo se quiso, cómo es y cómo debe ser,' in Primer informe temático 2006-2007 del Programa Nacional de Resarcimiento: La vida no tiene precio: Acciones y omisiones de resarcimiento en Guatemala (Guatemala City: Magna Terra, 2007). 
referring to the reparations program. According to the Real Academia Española dictionary, resarcir means indemnizar (to compensate economically), reparar (to repair) and compensar un daño, perjuicio o agravio (to compensate for damage, a disadvantage or injustice). In the agreement, resarcimiento is interpreted only as economic compensation for victims. The use of resarcimiento in the Guatemalan context refers to what Pablo de Greiff describes as the narrower sense of the English term 'reparation,' which is used in the design of programs with mass coverage and refers to 'attempts to provide benefits directly to the victims of certain types of crimes. ${ }^{14}$ Notably, the use of the verb resarcir and its noun, resarcimiento, were uncommon in daily language in Guatemala prior to the national debate on the creation of the PNR. Today, people associate these words with the conflict and, more specifically, with the financial compensation provided by the PNR.

The term reparación in the Guatemalan context denotes the conjunction of the search for justice, truth-seeking efforts (such as exhumations of clandestine graves for forcibly disappeared people) and initiatives to recover historical memory. The debate on reparación alludes to the term 'reparation' in international law, which refers to all reparation measures aimed at redressing human rights violations. ${ }^{15}$

The debate on resarcimiento gained momentum in 1999, when the presidential candidate for the Guatemalan Republican Front, ${ }^{16}$ Alfonso Portillo, promised to pay former PAC members for defending the country and private property against communism. ${ }^{17}$ This and subsequent demands for payment by ex-civil patrollers in several areas of the country in 2002 made political room for negotiations between the Portillo government and civil society for a reparations program. In 2003, based on the obligations assumed by the state in the peace agreements and in the CEH recommendations, Portillo's government approved the PNR with an Executive Decree. $^{18}$

The PNR had an integral reparation design that consisted of five measures: material restitution, financial reparations, psychosocial reparation and rehabilitation, honoring civilian victims and cultural reparation. Because of a lack of political will, differences among civil society organizations and the PNR's weak legal basis, implementation was postponed until 2005, when a new Executive Decree was promulgated that contained regulations for a restructured PNR. ${ }^{19}$ Although the

14 Pablo de Greiff, 'Justice and Reparations,' in The Handbook of Reparation, ed. Pablo de Greiff (Oxford: Oxford University Press, 2006), 453.

15 Ibid.

16 This is the party of General Efraín Ríos Montt, accused of genocide and massacres perpetrated during his 1982-1983 dictatorship. The PAC system was imposed under his command. As many as a million individuals are estimated to have patrolled the villages at the peak of the conflict. Margaret L. Popkin, Las Patrullas Civiles y su legado: Superar la militarización y polarización del campo Guatemalteco (Washington, DC: Robert F. Kennedy Memorial Center for Human Rights, 1996).

17 See, for example, Ricardo Sáenz de Tejada, ¿Víctimas o venecedores? Una aproximación al movimiento de los ex PAC (Guatemala City: Facultad Latinoamericana de Ciencias Sociales, 2004).

18 Acuerdo Gubernativo 258/2003.

19 Acuerdo Gubernativo 619/2005. 
original measures remained, individual financial compensation was prioritized for several reasons, including that the implementation of individual financial compensation is the 'easiest' to implement of the five measures recommended, and because victim organizations strongly demanded it. The beneficiaries were survivors of torture and sexual assault and relatives of victims of illegal executions, massacres and forced disappearances. The amounts offered were 24,000 Guatemalan quetzals $(\$ 3,300)$ for a deceased relative and $10,000-20,000$ quetzals $(\$ 1,370-\$ 2,750)$ for sexual assault and/or torture. Between 2005 and December 2007, the PNR compensated 12,126 beneficiaries, most of whom were elderly women. ${ }^{20}$ The total amount of beneficiaries increased in 2008 (10,477 individuals), ${ }^{21}$ and in the five first months of 2009, the PNR compensated approximately 10,500 beneficiaries. $^{22}$

\section{The Conflict in Alta Verapaz: Some Facts and Figures}

Few guerrilla movements operated in Alta Verapaz until the early 1980s, when the Guerrilla Army of the Poor moved into the area near the El Quiché department. ${ }^{23}$ The Alta Verapaz department suffered its first massacres in 1976, followed by massacres in the Chisec and Panzós municipalities in 1978. These massacres were caused by conflicts over land, and they occurred prior to the arrival of the guerrillas. A study of the historical memory of 20 Q'eqchi' communities chiefly located in the Cobán municipality found that the semifeudal system in place at the time on the fincas (large plantations or farms) was the main cause of conflict. ${ }^{24}$ The system was characterized by a lack of freedom, miserly salaries, high workloads, abuse and a lack of educational opportunities.

From 1981 to 1983, Chisec, Cobán and San Cristóbal were severely affected by the internal conflict. The CEH report indicates that 55 massacres occurred in Alta Verapaz during this period, while the REMHI report records 63 massacres. ${ }^{25}$ The $\mathrm{CEH}$ found that Alta Verapaz was the third-most affected department in terms of human rights violations, after El Quiché and Huehuetenango, and that the Q'eqchi' were the second-most affected ethnic group. ${ }^{26}$ The REMHI report notes that Alta Verapaz was the second-most affected department in terms of the number of registered victims and acts of violence, and that the Q'eqchi' were the worst-hit

20 The total amount of economic compensation was \$37 million. See, National Reparations Program, Informe de la evaluación conjunta del Programa Nacional de Resarcimiento y de los Programas de Apoyo al PNR de GTZ y PNUD (2007).

21 The total amount was almost \$32 million. See, Claudia V. Samayoa, 'Análisis de las medidas de resarcimiento a las víctimas como parte del proceso de reconciliación 1996-2008,' in Secretaria de Paz, Entre pasado y olvido: Políticas de reconciliación en Guatemala, 1996-2008 (2009).

22 Personal interview, Miguel Itzep, president, National Victims' Movement Q'anil Tinamit, Guatemala City, Guatemala, 6 May 2009.

23 Richard Wilson, Maya Resurgence in Guatemala: Q'eqchi' Experiences (Norman, OK: University of Oklahoma Press, 1995); Alfonso Huet, 'La diócesis de la Verapaz y el conflicto armado,' in Rescatando la memoria del camino: Diócesis de Verapaz 1935-2003 (Cobán: Centro Ak'kutan, 2003).

24 Alfonso Huet, Nos salvó la sagrada selva: Memoria de veinte comunidades Q'eqchi'es que sobrevivieron al genocidio (Guatemala City: Imprenta Maya Na'oj, 2008).

$25 \mathrm{CEH}$, supra $\mathrm{n} 6$ at vol. 3; REMHI, supra $\mathrm{n} 6$ at vol. 4.

$26 \mathrm{CEH}$, supra $\mathrm{n} 6$ at vol. 2. 
ethnic group in the country in terms of the number of victims. ${ }^{27}$ According to Monseigneur Flores, the bishop of Cobán during the 1980s, at least 40 percent of the Q'eqchi' were displaced from their communities and some 20,000 were forced to live as internally displaced persons, hidden for years in the mountains. ${ }^{28}$ These people struggled to survive in extreme conditions and were constantly forced to move from camp to camp, resulting in deaths from hunger, disease and susto. ${ }^{29}$ The military set up PACs in the department in order to extend its control over the region. By the time the patrols were dismantled in 1996, this department had the second-highest number of patrollers in the country at 72,699. ${ }^{30}$

The army also manipulated various symbols and names in Q'eqchi' culture and spirituality for its own purposes. ${ }^{31}$ Mayan Q'eqchi' spirituality surrounds daily activities such as agriculture and health issues. Tzuultaq'a ('Hill-Valley' or mountain spirits) is a central concept determining the identity and being of the Q'eqchi'. It is omnipresent and guides all actions of daily life. The idea of a personal, transcendent God is not inherent in this cosmovision; however, the Q'eqchi' do not ignore the Christian god and the majority are Catholic. Tzuultaq'a 'yo'yo' means that Tzuultaq'a lives and is keeper of the earth and all its inhabitants. ${ }^{32}$ The Q'eqchi' must ask permission from Tzuultaq'a with an offering (mayejak) to cultivate land. One clear case of the army's manipulation is a sign above the entrance to the Cobán military base, which reads, 'Military Base of Cobán, Home of Soldier Tzuultaq'a.' As one colonel stated, 'We are like the spirits of the mountain, because, just like them, we control the land and have dominion over all those who dwell in our territory. ${ }^{33}$

Toward the end of the 1980s, social reconstruction was proceeding slowly because of a lack of aid from government and national and international organizations. Even today, the state, international development aid agencies and nongovernmental organizations are not strongly represented in projects designed to support survivors in Alta Verapaz as compared with other regions. Nevertheless, in the 1990s, two communities from different microregions in Cobán did set up initiatives. In November 1995, in the Saha'kok region, a huge white cross was erected on

REMHI, supra $\mathrm{n} 6$ at vol. 4 .

Carlos Y. Flores, Bajo la cruz (Cobán: Centro Ak’kutan, 2001).

29 Huet, supra n 24. The closest translation of susto is fright or spirit loss. Among the indigenous peoples of Meso america, illness is more often associated with losing one's spirit than with being possessed by a spirit. The causes of susto, or the loss of one's spirit, vary and may include falling on a riverbank or in the forest, undergoing a stressful event, receiving a justified punishment for one's sins and witchcraft. The loss of the spirit can be temporary or permanent. See, Wilson, supra 23; Agustín Estrada Monroy, Vida esotérica Maya-Kekchí (Guatemala City: Ministerio de Cultura y Deportes, 1990).

30 CEH, supra n 6 at vol. 2 .

31 The CEH report recognizes that the conflict caused a rupture in the Mayan social fabric and the indigenous authority system, and that it disrupted social norms and elements of cultural identity. It also describes how the army deliberately destroyed sacred places. CEH, supra n 6 at vol. 4 .

32 See, Estaban Haeserijn, 'Filosofía popular de los K’ekchi' de hoy,' Guatemala Indígena 10(3-4) (1975): 44-54; Carlos Rafael Cabarrús, La cosmovisión Q'eqchi'e en proceso de cambio (San Salvador: UCA Editores, 1979); Monroy, supra n 29; Wilson, supra n 23.

33 Quoted in Wilson, supra n 23 at 242. 
the hill of El Filo, with two marble plaques bearing the names of 916 victims. This was the result of an extensive, well-coordinated process involving 28 communities across an area of 600 square kilometers. In 1994, a number of elders had dreamed of a large white cross emerging from a mountain, which was interpreted as 'a supernatural sign from their disappeared relatives who died during the violence and had not been buried in accordance with traditional practices. ${ }^{34}$ Each year since 1995, on 3 November and the Saturday before Easter, a Mayan ceremony and community celebration takes place near the cross to commemorate the loss of loved ones. ${ }^{35}$

Several years later, in Xalab'e, a remote community in the Nimlasachal region, another large cross was erected to commemorate 468 victims from 24 communities. This cross, surrounded by mountains, stands in the middle of the area where the massacres took place. This initiative was given support by REMHI in Alta Verapaz, the Asociación de Desarrollo Integral Comunitario Indigena and the Secretaría de la Paz.

Both crosses are the result of spontaneous, community-based and local processes of reconstruction of historical memory. ${ }^{36}$ The names on the marble plaques belong not only to victims of the massacres but also to people who disappeared or died from famine, malnutrition, disease or susto in the mountains. Both plaques also include the names of victims of PACs in the regions.

\section{Nimla Rahilal: The Conflict as Great Suffering and Pain ${ }^{37}$}

According to the UN Development Programme, 92.8 percent of the population in Alta Verapaz is indigenous, with the majority being Q'eqchi' and monolingual. ${ }^{38}$ For a better understanding of Q'eqchi' perceptions of reparation, it is necessary to examine the logical relations and semantic fields hidden in Q'eqchi' words referring to the conflict. ${ }^{39}$ This explains Q'eqchi' survivors' cultural understanding of the conflict and provides a background for analyzing the linguistic tangle regarding redress and reparation attempted below.

34 Flores, supra 28 at 43.

35 This began in the same year that the agreement on the establishment of a commission to clarify past human rights violations was signed in Oslo, Norway. At that time, no communication occurred between macro- and micro-level initiatives.

36 These can been seen as examples of local-level initiatives as described in Laura Arriaza and Naomi Roht-Arriaza, 'Social Reconstruction as a Local Process,' International Journal of Transitional Justice 2(2) (2008): 152-172.

37 For this section, linguistic workshops were conducted with survivors (April 2007), legal translators from different judicial institutions (April 2007) and linguists (August 2007). In addition, the dictionary of Esteban Haeserijn, Diccionario K'ekchi' Español (Guatemala City: Piedra Santa, 1979), was consulted.

38 UNDP, supra $n$ 8. The level of monolinguism is 65.7 percent - the highest in the country.

39 Edgar Esquit Choy and Carlos Ochoa García's argument that this method is a fundamental step in the analysis of the Mayan order is useful. Therefore, this author suggests that applying it to such issues as reparation, reconciliation, healing, justice and truth is necessary. See, Edgar Esquit Choy and Carlos Ochoa García, eds., Yiqalil q'anej kunimaaj tziij nimaq tzij: El respeto a la palabra: El orden jurídico del pueblo Maya (Iximulew, Guatemala: Centro de Estudios de la Cultura Maya, 1995). 
Although the majority of Q'eqchi' are Catholic, and despite the presence of evangelical churches, Mayan spirituality is maintained. ${ }^{40}$ In the Mayan worldview or cosmovision, no distinction is made among the social, natural and sacred spheres that make up the cosmos. ${ }^{41}$ The concept 'sacred' refers to 'that which is considered superior, worthy of respect and worship, and with regard to which all people and communities are required to carry out a specific duty,' and which 'assumes that interrelations exist between all elements of Creation and that all elements of Creation have a role in maintaining a Natural balance. ${ }^{32}$ In Q'eqchi', the word loq' refers to the sacred, or holy.

An analysis of transgressions of the sacred and of the Q'eqchi' normative system is beyond the scope of this article, ${ }^{43}$ but it is useful to highlight the concept of muxuk, which refers to desecration, defilement and violation of the sacred or spiritual value of something. The term also carries the connotation of sexual assault, as in the expression, xmux ru li ch'ina ixqa'al, which means 'the girl was raped.' It is also possible to desecrate Tzuultaq'a, corn, a rock, a tortilla or a house by displaying unacceptable behavior. An example of muxuk of food is when children enter a house and defile food given to visitors. As people do not always own a table, visitors put their coffee or bowl of food on the ground. If children suddenly enter, dust from the ground can fall onto the dishes. In this sense, the expression, xoo'e'xmux, which occurs frequently in interviews with survivors, means 'they desecrated the cosmos and us as humans' and clearly reflects the desecration of the natural, social and spiritual worlds caused by the conflict. One interviewee who was internally displaced noted,

I can say, the muxuk. First they defiled our lives, which means that they dishonoured lives, they killed our parents and they raped our women, we can say, our family. Maybe we can say that the ladies were raped, all of us, this is muxuk. They desecrated the deity of our subsistence, they burned it ... They burned the holy cornfields. This is desecration: they desecrated the holy beans, burned all the holy calabash.

The impact of the conflict was so disastrous that surviving Q'eqchi' victims, including former PAC members, use the term nimla rahilal when referring to the war period. Nimla means 'large' and rahilal means 'suffering' and 'pain' (physical, emotional and spiritual). Nimla rahilal refers to pain that is the result of a

40 Nonetheless, the idea of a Mayan (Q'eqchi') culture as a homogenous whole is problematic. Instead, the complex, fluid and hybrid character of culture should be acknowledged. See, for example, Jane Cowan, Marie-Bénédicte Dembour and Richard Wilson, eds., Culture and Rights: Anthropological Perspectives (Cambridge: Cambridge University Press, 2001); Pedro Pitarch, Shannon Speed and Xochitl Leyva Solano, Human Rights in the Maya Region: Global Politics, Cultural Conditions and Moral Engagements (Durham, NC: Duke University Press, 2008).

41 See, Coordination of Organizations of the Maya People of Guatemala Saqb'ichil (Saqb'ichilCOPMAGUA), Más allá de la costumbre: Cosmos, orden y equilibrio: El derecho del pueblo Maya de Guatemala (Guatemala City: Editorial Servicios San Antonio, 1999); Esquit Choy and Ochoa García, supra n 39.

42 Saqb'ichil-COPMAGUA, supra n 41 at 68.

43 For an in-depth analysis of Mayan Q'eqchi' normative system and Q'eqchi' survivors' perspectives on justice and reconciliation, see, Lieselotte Viaene, 'The Internal Logic of the Cosmos as "Justice" and "Reconciliation": Micro-Level Perceptions in Post-Conflict Guatemala,' Critique of Anthropology (forthcoming 2010). 
'final' loss; for example, the loss of a family member or of a harvest, home or money as a result of natural disaster. A final loss implies a pain that cannot be relieved - an irreparable loss. We may assume that the affected Q'eqchi' perceive the conflict as a problem of extraordinary dimensions and as a great suffering that led to permanent losses. Conveying this view, one internally displaced interviewee said,

But we will never forget the real pain, our deceased mother and father, because they will be with us always. It is like a thorn in our souls. It is like having a knife in our stomachs.

Another interviewee, a former PAC member, said,

It is difficult now. It is difficult for us to come together as one, because it has all fallen apart, yes. You could say that it is like an ants' nest that was destroyed or a beehive: they all go their own way, you cannot bring them together anymore.

The conflict strongly affected the social, material and spiritual worlds of the Q'eqchi'. The counterinsurgency measures violated not only their human rights but also social and spiritual norms established by the communities, which led to the destruction of their tuqtukilal (tranquility, peace and harmony).

\section{Linguistic Tangle: Redress, Reparation and Compensation}

Since 2005, two PNR offices have been active in Alta Verapaz, one in Cobán and the other in Panzós. The regional office in Cobán deals mainly with Q'eqchi' and Poqomchi' victims, but, as the Q'eqchi' are the largest group, the language generally used for administrating the program is Q'eqchi'. As the PNR was designed and implemented in Spanish, the regional office had to translate such concepts as resarcimiento, reparación and compensación (compensation) to explain the PNR's mission and purpose. This was not a simple task. For example, the key concept, resarcimiento, does not exist in the Q'eqchi' language, so the office head requested aid from the Academy of Mayan Languages in Cobán in finding an adequate Q'eqchi' term. ${ }^{44}$ The academy proposed k'irtasink, which means 'healing.' The office disagreed with this translation, noting that in accordance with Q'eqchi' thinking it is impossible 'to heal the past of the armed conflict.' After discussion, it decided on xiitinkil li raylal (rahilal), ${ }^{45}$ which means 'mending the suffering, the pain,' although the verb xiitink generally refers to mending damaged fabric.

According to the Q'eqchi', it is impossible to 'repair' damaged fabric, as one can only mend the tear. The office director argues that xiitinkil li raylal alludes to

44 Personal interview, Francisco Pop, coordinator of the PNR regional office, Cobán, Guatemala, August 2007.

45 In the popular Q'eqchi' version of the PNR's official documents, raylal is used, but according to the Academy of Mayan Languages' official grammatical rules, the appropriate word is rahilal. 
'repairing/mending' the current social tissue, as the PNR's objective is not to create a new identity or culture or to reverse the situation to what it was before the conflict, as what was lost during the conflict can never be 'repaired' or regained. While the expression may be used as a metaphor to indicate the 'repairing/mending' of social tissue, it does not truly reflect the affected people's views on the conflict, as was made clear in a statement by a Q'eqchi' individual who has had much experience in dealing with the elders of various affected communities:

Mending (xiitink) is as if one small part were damaged and in need of mending. However, this is not a small part, what [the army and government] did. Yes, what they did was enormous.

In order to understand the lived experiences expressed in the interviews presented in the next section, a provisional semantic analysis is provided of two key concepts that appear in the oral and written discourses of Q'eqchi' survivors, of PNR administrators and in the popular Q'eqchi' version of the PNR brochure. ${ }^{46}$ These concepts, reeqaj and k'ajk'amunk, refer to the mechanisms used to maintain balance in interpersonal relationships and are expressions of reciprocity.

Reeqaj usually overlaps two semantic fields. Its English translation is 'compensation' (or refund) and 'substitution' (or replacement). One context in which reeqaj is used is compensation for material damages. If a cow has been grazing in a cornfield, the cow's owner compensates the affected family for the damage. This compensation can take the form of money or of a single task, such as weeding the field or helping to build a house. The form and timing of compensation depends on the agreement reached by the parties. Furthermore, compensation must equal the material value of the damage. As a result of the internal logic of the cosmos, however, reeqaj can also be negative compensation, for example, when it takes the form of an incurable disease that strikes someone as a result of improper conduct, such as humiliating, insulting, mistreating or killing someone. The other meaning of reeqaj is replacement, for example, when a father calls the child who bears his name weeqaj (my replacement). Reeqaj also refers to a special doll that is left at a place where someone experienced susto and thus lost his or her spirit. $^{47}$

The word k'ajk'amunk refers to the recognition and gratitude expressed by one person toward another for a task performed, help given or service rendered. One example would be the gift of 20 corncobs each to those who helped a family harvest its crops. The form of this acknowledgment depends on one's economic situation. It is assumed to be a symbol of reciprocity and of mutual aid. As a result of economic changes, the practice of offering corncobs has been replaced by giving

46 National Reparations Program, Un camino hacia la dignidad(2007); National Reparations Program, Xmolam li awab'ejilal re xiitinkil li raylal: Jun xb'ehil li loq'al (2007).

47 This human-shaped doll is made from pom (resin with a strong aroma), beeswax and a lock of hair from the person who experienced susto. Leaving this doll behind is part of the b'oqok xmuhel (calling the spirit) ritual, which is carried out to help the spirit return to the person. Thus, reeqaj also has a spiritual connotation. 
money, although when offering money, people still say, a'in lixk'ajk'amunkil li xabunu we, or 'Here is a token of recognition for what you did for me.' This shows that k'ajk'amunk has a significance beyond simple payment, implying recognition and gratitude.

\section{Toward an Inclusive and Culturally Sensitive PNR}

Everything we have said today, I hope that it gets into the hands of the president. Because nobody else had come to listen to us, nobody had come, it is possible that he [the president] does not know of our suffering.

—Compensated widow, focus group discussion, 5 September 2007

This section provides an overview of five critical points regarding the functioning of the PNR that emerged during various focus groups and individual interviews with Q'eqchi' survivors. ${ }^{48}$ Although they reveal the program's inadequacy, the points raised offer suggestions for feasible ways in which to attune the PNR to its beneficiaries' needs and improve its local and cultural sensitivity.

The five key concepts are: life is priceless; compensation should be offered for lost material possessions; collective remedies should be available; access to and divulgement of the historical memory of the communities are necessary; and the lost spirit must be called. The views expressed here are not necessarily representative of what all Q'eqchi' victims think about reparation, but the uniformity of the interviewees' views regarding certain issues suggests that these views are widespread.

\section{Life Is Priceless}

Financial compensation is the only measure that the PNR has thus far implemented. The PNR regional office in Cobán uses the expression k'ajk'amunk chi tuminal (recognition and gratitude through money) to refer to financial compensation. K'ajk'amunk should not be used in this context, however, because the state caused the nimla rahilal (great suffering and hurt) and is now offering monetary compensation. Its offer could be considered aid, but not recognition and certainly not gratitude. Therefore, the use of k'ajk'amunk in the context of reparation for the conflict is a distortion of the word, which should be used in a positive context, describing when a person who receives help gives something in return. Moreover, 'the checks,' as the government's monetary compensation is commonly called, fail

48 The field data used in this article was mainly collected during the time of the Oscar Berger government. With the new Álvaro Colom government of 2008, the discourse on resarcimiento was revised, and now pretends to be resarcimiento integral, implementing all five measures. In the field, no profound changes are yet visible. According to the current director of dignification measures of the PNR, Rafael Herrarte, the head office is designing a methodology of community intervention, but implementation is still pending. Personal interview, Rafael Herrarte, Guatemala City, Guatemala, 18 March 2009. Further, in 2009; the PNR started implementing the measure of material restitution through a pilot project of house building. The budget is $\$ 12.5$ million and will benefit in total 70 communities throughout the country, which will each receive 20 houses. Personal interview, Miguel Itzep, Guatemala City, Guatemala, 6 May 2009. Currently, in the Alta Verapaz department. The PNR is implementing two pilot projects (Chisec and Nimlaha'kok) on housing restitution. Personal interview, Diana de Buena Fé, coordinator, PNR regional office, Cobán, Guatemala, 28 April 2009. 
to provide real satisfaction for either the remedied victims or for those whose cases are still pending.

One reason for this is that payment generates a strong feeling of guilt among Q'eqchi' victims in relation to their lost loved ones. One internally displaced man stated,

K'ajk'amunk, paying for violence, we do not like it either. It is like I said, they are only paying for the dead. It is like for my mother, they are going to pay me for her, I will eat my mother, I will chew my mother. What I would like is for all those who suffered from the violence to be helped.

Another reason is the cost of applying for compensation. The PNR states that the procedure for requesting any form of resarcimiento is free, but in practice, it demands a large monetary investment in travel, documentation, translators and so forth. Often, victims must incur debt to complete the process. According to one compensated widow,

It is as though the president took it [the compensation] away again, because the president said, 'For this compensation you need to show these documents.' They say, 'If you do not show all these documents,' they say, 'you cannot get any help' ... And where do you need to get these documents? From the municipality. Some cost six [quetzals], some cost fifteen, some cost five. We paid a lot of money.

The biggest obstacles victims face in the process are their lack of necessary official documents, such as identity cards and birth and death certificates, and mistakes made in the first and last names on the documents that do exist. It should be mentioned that on the fincas and in certain small villages, people used to lend their documents to others for tasks such as birth registration, partly because they were afraid of the country's severe anti-vagrancy law. ${ }^{49}$ Thus, many children were registered under incorrect surnames. In some cases, civil registrars were negligent and misspelled people's names. ${ }^{50}$ One compensated victim noted,

The money that I spent in the municipality, that is money that was coming to us. If the government had really wanted to help us, they would not have asked us for a single document, because when they killed our parents, they did not ask for their papers either. And they are considering giving me a little bit of aid, but they want a lot of documents in return. This means that the money we gave to the municipality is simply the money that they then gave back to us.

Moreover, many victims face racism and discrimination in their contact with municipal registries. While most beneficiaries of the PNR are monolingual Q'eqchi', municipal administrators have little knowledge of the Q'eqchi' language.

49 In 1930, the government under the dictator, General Jorge Ubico, passed the Act against Vagrancy, which stated that all farmers not employed by a landlord or owning a certain amount of land were to be considered vagrants. Vagrancy was punishable by forced labor on public works. The indigenous population thus faced the choice of either working on the fincas or doing forced labor in road construction.

50 Civil registrars were always Spanish speakers and unfamiliar with the Q'eqchi' language, which has no similarities with Spanish. As the vast majority of Q'eqchi' were illiterate, they could not correct the spelling of their names. 
Therefore, victims must hire tramitadores, individuals who speak Q'eqchi and are familiar with legal procedures, to address the administrators. Act 19/2003 recognizes the official use of indigenous languages and states that they must be used in all public services. In practice, this remains problematic.

These narratives show that the process of applying for financial compensation costs victims time and money. Many discover that they lack the correct documents to complete it. Instead of facilitating the process for those already in a vulnerable position, economically and legally, the PNR complicates things. With its strict bureaucratic requirements, the program is revictimizing the victims instead of executing its intention of redressing the past and healing wounds.

Field research data shows that victims perceive monetary compensation as aid (tenq) from the state, rather than as the reparation due to them. Moreover, many believe that assistance is coming very late - more than 20 years after the nimla rahilal. Victims who participated in the research done by the CEH and REMHI stated during focus group discussions that they had been told for years that help was on the way, but that the promises remained unfulfilled. ${ }^{51}$ During the first years after losing their spouses, their houses and all their belongings, widows, survivors of massacres and internally displaced persons struggled to live, only managing to do so with great difficulty and suffering. Therefore, they see the current monetary compensation as a form of aid for their children, and especially for their grandchildren, in recovering lost opportunities. As one widow said,

My children suffered. If their father had been alive today, maybe I could, maybe I would have been a nurse. Maybe he would have been a teacher or something else. Maybe he would have been a lawyer, because their father was a really good man, the father of my children.

A major reason for criticism of the PNR is that former PAC members have already received their payments, ${ }^{52}$ while the majority of program beneficiaries have been kept waiting, sometimes for over two years. The state's unequal treatment often generates friction in communities and reopens old wounds. In some cases, the resarcimiento, as now executed, serves to reveal the war's complexity. During field research several cases came to light of men who had lost family members through the army's actions but were still forced to patrol their villages. These men appear on the PAC lists and therefore have lost the right to be beneficiaries of the PNR. In Guatemala, the harsh reality of the 'victim-perpetrator' identity is seriously underestimated and even neglected, not only by the state but also by civil society and specific organizations that work with victims.

51 Indeed, as Lisa Laplante and Kimberly Theidon note, an implicit contract exists between giving testimony to a truth commission and demands for acknowledgment and redress. Lisa J. Laplante and Kimberly S. Theidon, 'Truth with Consequences: Justice and Reparations in Post-Truth Commission Peru,' Human Rights Quarterly 29(1) (2007): 228-250.

52 The total payment of $\$ 700$ was awarded in three instalments from 2003 to 2007, depending on the region. Not all PAC members received all three payments because of bureaucratic problems. 
The idea articulated by interviewees that life is priceless reveals frustration with economic compensation. Nevertheless, the interviewees offered several suggestions for complementary approaches to the actual reparation policy.

\section{Restitution for Destroyed Possessions}

During the interviews, victims asked for restitution or compensation from the government for destroyed material possessions, such as houses, livestock, cornfields, beans, clothes, millstones and traditional instruments. One internally displaced woman stated,

Our things, our livestock, our chickens, all our belongings, the cups, crates, pots, mill stones, our corn, our cornfields, they took it away and left us with nothing. And our clothes, we do not have clothes anymore, all our clothes were burnt, nothing is left, we only managed to save two items, nothing was left of my children's clothes. With a lot of effort, the flesh was saved, the person as such, but we have nothing left. And now we need to replace all these things, all our belongings, our animals, the seeds that were destroyed, that were taken away by the soldiers. This needs to be compensated, it does not stop here.

Remarkably, survivor interviewees used the word reeqaj when making such statements. The term reeqaj arguably has a deeper meaning in the context of the conflict. The state cannot return deceased relatives to grieving families, but by giving monetary compensation for their losses, it causes feelings of guilt. When victims request reeqaj for their lost possessions, they are not referring only to material compensation. The possessions equally had spiritual meaning: a house symbolizes warmth, love, a place to rest, a place where values and culture are transferred and a place containing the altar where a family can make contact with the spirits of its deceased relatives. In order to meet victims' demands for reeqaj of their belongings, the state must not only replace their material possessions but also enable them to regain their lives in the atmosphere of tuqtukilal - of tranquility. According to a compensated widow,

They [the PNR] redressed very little. They should give us our own place, they should give us our homes, everything. Maybe they will compensate us for a little, when they will, it will be very little. Even if it was a little, a pinch. They already compensated a little, they should give us various things. That way our hearts could rest, we would have our house.

Following the semantic logic of the term reeqaj, victims want restitution that equals the value of their lost possessions. The interviewees implied a high degree of dissatisfaction among the displaced people regarding the houses that the PNR claims it will be offering, as these small cubes do not have the same value (material or spiritual) as the houses they lost. ${ }^{53}$

53 The houses of the pilot project are only six meters by six meters. Personal interview, Diana de Buena Fé, Cobán, Guatemala, 28 April 2009. Prior to the conflict, survivors had one or two wooden houses that were on average 12 by 15 meters. 
One major request of survivors is that they be granted titles to land, as titles are a precondition of obtaining a house and a key requirement for rebuilding one's life. Because of the finca system, most Q'eqchi' do not possess any land. Heated land conflicts continue to this day in Guatemala, with the highest concentration in Alta Verapaz. $^{54}$

\section{'We All Suffered': Collective Reparation}

Evidence from the interviews suggests widespread endorsement of complementary collective reparation measures. Currently, financial compensation is awarded on an individual basis, and the narratives show that this has caused a great deal of criticism and incomprehension among victims, both those already compensated and those whose applications are pending. Individual compensation creates guilt in relation not only to deceased relatives but also to others who have suffered but who, for bureaucratic reasons, do not receive compensation. Victims believe that all have suffered from the conflict, as demonstrated by the comments of one compensated interviewee:

And all my friends who are here are very sad because they have not even received a little bit of help. Our brothers have seen nothing. This is very painful what we are going through. There are elderly people here, very elderly, who still have not been helped with their dead.

Many Q'eqchi' had to flee their villages because of scorched earth campaigns. They hid in the mountains for years, with many dying of hunger, malnutrition and susto due to the poor living conditions. These victims have problems understanding and accepting that the PNR distinguishes between victims who died from these causes and those who died from bullets or machetes, as all deaths were a result of persecution during the conflict. ${ }^{55}$ Research on the reintegration of internally displaced persons shows that this relative homogeneity is a characteristic of all the displaced communities that returned to Cobán. ${ }^{56}$ Members of communities who shared the experience of displacement want everyone to receive both financial compensation and restitution for their destroyed belongings. A leader of Chicoj Raxquix, a community of internally displaced people who received individual economic compensation, explained:

54 Between 2000 and 2006, 464 cases of land conflict were recorded in Alta Verapaz, with a concentration in Cobán and San Pedro Carcha. Secretaría de Asuntos Agrarios Presidencia de la República Guatemala, Las ocupaciones de tierra en Guatemala: Caracterización y Líneas de Atención: Informe final (2007).

55 At the end of 2007, the National Reparation Commission (Comision Nacional de Resarcimiento, or CNR) approved the measure of individual financial compensation for relatives of those who died as a result of forced internal displacement. The complete implementation of this measure is still pending. In Alta Verapaz, only a few individuals have received this compensation, although there are many cases pending. Personal interview, Diana de Buena Fé, Cobán, Guatemala, 28 April 2009.

56 Association for the Advancement of the Social Sciences in Guatemala, ¿Dónde está el futuro? Procesos de reintegración en comunidades de retorno (1992). 
We should all be given something, we all suffered under the violence equally, we were all attacked. There is a sense of urgency now, the government should meet with everybody or should give out all the aid. Well, in order for us to have peace, like when we were living in the mountains, when we shared our tortillas, shared our bananas, we all had very little and we shared it with everyone. Nobody was left without food, there was always a little, we ate a little, we tasted a little. Well, that is how the government should act as well, so that we might all get a little from what the government is handing out ... Only those of us who suffered violence are brought together, but what I want now is aid and for it to come directly to our village and to let us deal with it. We will coordinate it, we will oversee it, we will divide it among our friends and we will know who is entitled to how much. But the government is only giving aid to one person at a time, so we are not at all satisfied.

In February 2007, Chicoj Raxquix filed a petition with the PNR, signed by 120 people, to obtain material compensation and houses as a group. They have not yet received any response. ${ }^{57}$

\section{Recovering Historical Memory}

The interviews reveal not only victims' aspiration to receive material compensation but also a desire and need to recover historical memory and share experiences in affected communities. One internally displaced interviewee said,

We still attach great value to telling these stories, the truth, because we do not want to let the names of our friends be forgotten by not mentioning them, we have to mention them, because they are not to blame. They are not to blame, because they didn't do anything, I mean, our friends who were killed and tortured and today we want to hear about them.

Although the $\mathrm{CEH}$ recommended the organization of a large-scale campaign to disseminate its final report, neither the original version nor the Q'eqchi' version has been distributed on a large scale in Alta Verapaz. ${ }^{58}$ Only Sister Rosario Celis and her group of reconciliation promoters from a number of Alta Verapaz's affected communities have continued this work, within the framework of the follow-up phase of REMHI. Together, they have managed to spread the Q'eqchi' version throughout the communities with which they work. Sister Rosario has even introduced it in communities with a large PAC presence. This effort by REMHI is greatly valued by victims and former PAC members alike. Furthermore, an interesting initiative arose thanks to the dynamic created by a research project about the recovery of historical memory in 20 communities in Cobán. ${ }^{59}$ In 2006, after four years of research, the participants decided to create their own organization, the Resistance Committee of Surviving Q'eqchi'. The committee's central goal is to disseminate historical memory throughout the various communities of

'Documento Memorial de la Aldea Chicoj Raxquix del Municipio de Cobán, Alta Verapaz,' received by the PNR, 21 February 2007.

58

CEH, supra $n 6$ at vol. 5.

59 Huet, supra $n 24$. 
Alta Verapaz because its members feel that the suffering caused by the conflict should not be forgotten.

As mentioned above, the two memorial crosses erected by local communities were a result of local efforts to recover historical memory and to commemorate victims. These efforts have yet to receive official acknowledgment, however, whether from the mayor, the governor or a PNR representative, even after all these years. The state's lack of interest and recognition revictimizes the victims, as one elderly man from Saha'kok noted:

It is true, yes, that we saw this violence, that we suffered as a result of it. If we had not suffered this violence, then we would not have a cross [here in Saha'kok] with all the names of our deceased. And the government has never come to look at this cross, even though it is standing there. There they would see the names of our dead mothers, of the parents, the elders, our grandfathers and grandmothers who were murdered, you know, with the bombs, with everything, with machetes, also.

In fact, the four key points presented above fit closely with the original design of the national reparations program, which was never implemented, and contains the five measures mentioned above: material restitution, financial reparations, psychosocial reparation and rehabilitation, honoring civilian victims and cultural reparations.

\section{Calling for the Spirit that Stayed in the Mountains}

A final key point raised by interviewees was the importance of the spiritual side of healing wounds of the past. Healing rituals rooted in the Q'eqchi' cosmovision could address the problem of the wandering spirits of many internally displaced people. According to Q'eqchi' spirituality, the Tzuultaq'a lives. They also believe that each person - as well as many animals, plants and material objects - possesses a spirit (muhel) that accompanies him or her even after death. ${ }^{60}$ The root of muhel is $m u$, which means 'shadow.' A typical characteristic of muhel is the fragile link with its host; thus, one can lose one's muhel quite easily, with children running a greater risk of this than adults.

The loss of muhel can be temporary or permanent. If the loss becomes permanent, the person dies, because the muhel has left the body to reach its final destination in the mountains, to be with Tzuultaq'a. If the loss is temporary, it may manifest as a physical or mental illness or as muteness. These manifestations are regarded as characteristics of the state of susto. ${ }^{61}$ To regain one's muhel, a Q'eqchi' usually needs to carry out the ritual of b'oqok xmuhel or 'calling for the spirit.' The ritual may return one's spirit and restore all one's energy.

60 Ruth Carlson and Francis Eachus, 'El mundo espiritual de los Kekchies,' in Estudios cognitivos del Sur de Mesoamérica, ed. Helen L. Neuenswander and Dean E. Arnold (Dallas: Summer Institute of Linguistics Museum of Anthropology, 1977); Monroy, supra n 29; Wilson, supra n 23.

61 Monroy, supra n 29. 
Many who had to flee and survive in the mountains regularly suffered from losing their spirit. Susto was one of the major causes of death. ${ }^{62}$ Even today, some internally displaced persons suffer from the susto they had during their years in the mountains. This manifests itself mainly in their dreams, in which they relive persecution at the hands of soldiers and the PAC, the constant fleeing and their suffering. As one internally displaced elder explained,

Even today, even this week, two weeks already, I dreamed that we were once again up in the mountains. The soldiers came, we were up in the mountains and started to flee, we were running through the hills once again. That has been my dream ever since we suffered this violence, more than 20 years have passed. Almost 25 years, always this dream, only this is what I dream.

Another noted,

Our spirits remained up in the mountains, nobody brought them back down, nobody, nobody, nobody has gone up to see our spirits there. Who will go up to see, who would have thought of that? Our spirits have stayed there. That is why we dream. It is as though we were up there in the mountains once again, it is as though the soldiers are still haunting us when we sleep.

A Q'eqchi' spiritual guide (aj ilonel, or 'he who sees what is hidden') explained the cause, impact and means of redress for the spirit lost during the conflict:

Their spirits were not returned to them, that is why they still dream. It appears that they are suffering once again, it is as though the war has started again ... [You need to] recover the energy that you have lost, because being without the muhel, the spirit, this means that the person will be sick all the time, they will be thinking all the time about what happened, where it happened, where they were hiding, where they were found, where they were persecuted. This spirit is no longer inhabiting the person, it is no longer present in them. It is walking up there in the mountains, which is why they are dreaming, seeing, walking, feeling as though the problem, the armed conflict, is still there or will return. Why? Because their spirit has broken away. Now, carrying out the b'oqok xmuhel means recovering this spirit, making it return to its rightful [place], to where it should live, to where it used to live.

To recover spirits that are still wandering in the mountains, people need to go back to the places where each took fright and lost his or her muhel and carry out rituals. However, many of these places are now private property. During the conflict, many fincas were abandoned, but since then the owners have returned. Alternatively, because of displacement, new communities may have taken up residence there. Consequently, displaced persons need official permission to return to the sites where they experienced susto.

Despite the deep impact of such beliefs, organizations that offer psychosocial assistance to victims show a lack of interest in and respect for resources of indigenous healing. For example, the Guatemalan Forensic Team always appeals to one of the recognized organizations that offer psychosocial counseling, such as the Team of Communitarian Studies and Psychosocial Action, the Maya Center

Huet, supra n 24 . 
Saq'be', Utz K'aslemal and the Group for Mutual Support, to assist victims before, during and after exhumations. Only Saq'be, a Kakchiquel organization of Chimaltenango, exclusively applies Mayan knowledge on health and illness during its sessions. Unfortunately, because of the language barrier, the organization cannot be a real help in other Mayan regions at this point.

\section{Conclusion}

Few will contest that optimal redress should address the real needs and experiences of those affected by gross human rights violations. In fact, the success of a reparations program and its ability to alleviate the pain and suffering of survivors depends on whether victims can relate to its design and implementation. Therefore, the analysis and interpretation of victims' perceptions regarding the conflict are a necessary precondition and fundamental step in the design of the program. Unfortunately, in practice, victims' perspectives are often overlooked.

From a Q'eqchi' victim viewpoint, the PNR faces the impossible task of repairing the irreparable. Moreover, as is apparent from interviewee narratives, the PNR tends to elicit further suffering and frustration rather than gratitude or satisfaction in its intended beneficiaries. The perceived inadequacy of the program is mainly rooted in its prioritization of individual financial compensation, stringent legal and bureaucratic requirements and exclusion of those who died in the mountains from malnutrition, hunger and susto. Analysis of victims' perceptions and aspirations shows that the PNR also clashes with fundamental Q'eqchi' norms and values and that its implementation methods disregard both local and cultural dynamics and realities.

According to the logic of the Q'eqchi' cosmovision, as shown in the analysis above of the word reeqaj, a fundamental step toward repairing any damage is to reach an agreement, via negotiations and discussions, between the victim and the perpetrator on the conditions of reparation. This first step in the reparation process was omitted in the implementation and management of the PNR. Moreover, the problem of translating the key concept resarcimiento into Q'eqchi' and the semantic analysis of the words reeqaj and k'ajk'amunk demonstrate that the expectations of Q'eqchi' victims (and probably those of victims from other Mayan groups) were not considered or included in the PNR's design.

The interviewees' frustrations illustrate the challenges facing any reparations program, namely achieving completeness, comprehensiveness, complexity and coherence. ${ }^{63}$ Notwithstanding the fact that the critiques made by Q'eqchi' victims are not exclusive to the Q'eqchi', victim statements reveal the PNR's underestimation and undervaluation of cultural understanding and different conceptions

63 Pablo de Greiff, 'Introduction,' in The Handbook of Reparation, ed. Pablo de Greiff (Oxford: Oxford University Press, 2006). 
of reparation. ${ }^{64}$ Little research has been done on this issue, but some examples are available from other communities. For instance, survivors of a massacre in the Afro-Colombian community of Bojayá in 2002 show similar feelings of guilt for receiving individual economic compensation. Moreover, according to the researchers, this reparation measure produced a sensation of being in debt to one's ancestors. ${ }^{65}$ In Chile, a study on the impact of financial reparations on the Mapuche communities reports that these reparations distorted family relations and negatively affected family and community networks. ${ }^{66}$ It also mentions that this culture's conceptions of reparation were disregarded.

Although this article has presented several concrete points of criticism and frustration, it also suggests alternatives for improving Guatemala's reparation policy. The PNR should take up the thread of integral resarcimiento and tackle the practical challenges to making it more inclusive and culturally sensitive. A good starting point would be for PNR administrators to gain an understanding of beneficiaries' aspirations through community meetings.

Given that psychosocial assistance is part of comprehensive resarcimiento, the PNR should acknowledge the resources available in Mayan beliefs and practices, and the role of traditional leaders and healers in dealing with health issues. It should start exploring how it can reinforce indigenous knowledge about healing, and it should urge the civil society organizations involved to respect and include indigenous healing knowledge in their projects.

As experiences of the conflict differed from region to region, the PNR should be rooted in communities in order better to address specific local and cultural needs. This would not only stimulate the aspirations and empowerment of the people and communities but also help the PNR and its beneficiaries deal with and go beyond the discord caused within communities by the conflict. As the historical socioeconomic exclusion of indigenous people was one of the root causes of the conflict, it cannot be excluded from the debate on redress and reparation. The $\mathrm{CEH}$ has stated clearly that indigenous people's collective rights were fundamentally violated, so the implementation of locally adapted collective reparation measures should be seriously considered.

64 For example, a study in which victims from Chile, Argentina, El Salvador, Guatemala and South Africa were interviewed stresses that the significance of monetary compensation is controversial and problematic and that victims ask for acknowledgment that they were wronged, knowledge of perpetrators, justice and moral reparations, not necessarily for economic compensation. See, Victor Espinoza Cuevas, Maria Luisa Ortiz Rojas and Paz Rojas Baeza, Comisiones de verdad: ¿Un camino incierto?: Estudio comparativo de comisiones de la verdad en Argentina, Chile, El Salvador, Guatemala y Sudáfrica desde las víctimas y las organizaciones de derechos humanos (Santiago: Corporation for the Promotion and Defense of the People's Rights/Association for the Prevention of Torture, 2002).

65 Martha Nubia Bello, ed., Bojayá, memoria y río: Violencia política, daño y reparación (Bogota: National University of Colombia, 2005).

66 Elizabeth Lira, 'The Reparations Policy for Human Rights Violations in Chile,' in The Handbook of Reparation, ed. Pablo de Greiff (Oxford: Oxford University Press, 2006). 
In a broader context, we should not lose sight of the fact that the healing of wounds and national reconciliation will require both society's and the state's relations to be fundamentally restructured. This would be the root of the truly pluricultural state aimed at in the peace agreements. The powerful words of a Q'eqchi' widow reflect Guatemalans' ultimate aim in this regard: 'We do not want to suffer anymore, we want tranquility.' 